\title{
FARM TENANCY IN THE UNITED STATES
}

\author{
By Benjamin Horace Hibbard, \\ United States Census Bureat, Washington.
}

Are we becoming a nation of landlords and tenants? The question has been asked many times during the past quarter century, and very many times it has been answered in the affirmative. Tenancy has on the other hand frequently been called a stepping stone to ownership on the ground that a young man starting out as a farmer rents land for a few years, and later buys. That this is true to a great degree cannot be doubted since it has been shown by the census statistics that farmers of the lower age groups are more largely tenants than owners, while in the higher age groups tenants become few, and owners many. However, for the country as a whole, the proportion of tenancy seems to be increasing at a positive, though not rapid rate, suggesting that the stepping-stones of tenancy are getting somewhat farther apart and the passage over them to the ownership beyond becoming correspondingly more difficult of accomplishment. Possibly one or the other of these answers is correct, but before accepting either it will be well to make an analytical study of the case, since the United States is much too large, the farms too varied in character, and the farmers themselves too unlike to permit of many broad, safe generalizations.

With the possible exception of the negroes of the South there is no tenant class of farmers. That is to say, there are no considerable numbers of farmers who look upon themselves, or who may properly be looked upon, as probable life-long tenants. In contrast to this situation a great part of the English farmers have little prospect of becoming land owners, many in fact not even wishing to buy land since the return on money so invested is less than on other investments which they are disposed to make. In this country very few farmers rent land from choice, preferring, in substantially all cases it may be assumed, to become owners as soon as circumstances will permit.

The authentic history of tenancy in America extends over a period of but thirty years, 1880 being the first time a census of farm tenure was made. The following table shows for the United 
States as a whole, and for the five geographic divisions, the percentage of tenant farms to all farms at each census year, 1880 to I9Io.

\begin{tabular}{|c|c|c|c|c|}
\hline \multirow[t]{2}{*}{ Per Cent of Tenancy } & \multicolumn{3}{|c|}{ I 880 то I910 } & \multirow[b]{2}{*}{1880} \\
\hline & 1010 & 1900 & 1890 & \\
\hline United States .......... & 37.0 & $35 \cdot 3$ & 28.4 & $25 \cdot 5$ \\
\hline North Atlantic division & 18.2 & 20.8 & I8. 4 & 16.0 \\
\hline South Atlantic division & 45.9 & 44.2 & 38.5 & 36. I \\
\hline North Central division & 28.9 & 27.9 & $33 \cdot 4$ & 20.5 \\
\hline South Central division & 51.7 & 48.6 & 38.5 & 36.2 \\
\hline Western division ..... & I4.I & I6.6 & I2.I & 14.0 \\
\hline
\end{tabular}

It will be noticed that from I880 to I900, not only for the whole country, but for all of the geographic divisions except one, the proportion of tenant to owned farms shows an uninterrupted increase. In I880 out of every hundred farms in the United States 25 were operated by tenants, by 1890 the number had risen to 28 , by 1900 to 35 and stands for the last census at 37 . The number of tenant farms increased 130 per cent during the thirty years, while the owned farms increased but 34 per cent. If the same rates of increase should continue for another thirty years, one-half of all the farms of the country would be in the hands of tenants.

However, the rate of increase for the country as a whole has already slackened, and for the North Atlantic division, the Western division and four states of the South Atlantic division there has been a decrease in the proportion of tenant farms. In other words there has been a decrease in tenancy in the whole of the East to the north of North Carolina and in the greater part of the West including the western border of the Great Plains and from there to the Pacific Ocean. In number of states and in area, these two regions comprise about half of the United States. This leaves the Mississippi Valley, the Gulf States and three Southern States bordering on the Atlantic as the region within which the number of tenants has gained on the number of owners. It may be noted further that within the group of states in which the proportion of tenancy has decreased, it was already lower than the average for the country, and conversely in the sections in which it has increased, it was already high. That is to say, the movement had been in progress for a considerable length of time so far as a drawing apart of the proportion of tenancy in these sections was concerned, except that in the groups of states in which the decline in 
the proportion of tenancy has recently occurred there had previously been an advance at a slow, instead of a rapid rate. It is in the great grain-growing districts of the Middle West, and in the cotton and rice growing districts of the South, that tenancy las reached its greatest height and still shows the greatest tendency to increase. In the North the increase in tenancy is associated mainly with the land highest in price, and moreover, with land which has increased in price more rapidly than any other great amount of land in the country. In the South, tenancy is more prevalent than anywhere else in the United States and follows mainly the line of crops produced by the Negroes, for the most part cotton. Where the most cotton is grown the proportion of Negro farmers is highest, and there also the percentage of tenancy is highest. The difference between the tenant of the upper Mississippi Valley and the lower Mississippi Valley is very marked.

In the North he has, with few exceptions, enough farm equipment of his own to enable him to get along independently of the landlord in that regard. He owns probably a thousand dollars worth of live stock and implements. He rents a farm varying little in size from the average of the district in which he lives, perhaps 160 acres in Iowa, or 240 acres in South Dakota. The value of the land is about the average for all land of the neighborhood in which it is located, about $\$ 100$ an acre in Iowa, more than that in Illinois and less farther west and north. Thus the tenant of this part of the country owns a considerable amount of property and is in charge of a farm worth from ten to twenty thousand dollars. In the South a tenant usually owns very little live stock and very little in the form of implements, both classes of equipment being furnished in great numbers of cases by the landlord. Moreover, he rents a small instead of a large farm, usually 20 to 40 acres, and instead of managing it independently, works under the direction of his landlord. In neither East nor West are the tenant conditions so clear cut as in the Middle West or the South, due apparently to the prevalence of a greater proportion of specialized types of farming, some of which are quite usually carried on by tenants, some quite seldom.

Viewing the geographic divisions of states separately it is to be seen that the proportion of tenant farms follows in many cases quite closely the value of land per acre, in other cases the value 
of farms as units, while in still othar cases the determining factor seems very clearly to be the character of the farming to which the district is adapted. Beginning with the North Atlantic States it may be noticed that the value of land per acre corresponds very closely to the rate of tenancy. Counting New England as a unit, since some of the states are too small and too thickly dotted with cities to permit of a fair comparison with the states having great areas of farm land, the rank in value of land and in tenancy corresponds exactly.

As compared to the North Central States, the value of land for this whole group is low. The highest value per acre found in any one of the North Atlantic States is in New Jersey, and it is slightly below the average for the North Central States as a whole. Likewise the proportion of tenancy is lower. For New England the value of land is decidedly low, and correspondingly, the rate of tenancy is lower than in any other of the older states of the Union. Some important variations in the relation of price of land to rate of tenancy are found in the vicinity of the cities where there are a great number of suburban homes with sufficient land to be counted as farms. These are, with few exceptions, owned by their occupants and the value is above the amount justified by the agricultural capacity of the land.

Nevertheless the highest proportion of tenancy is found in connection with land highest in price within the states in which general agriculture predominates. For example in Pennsylvania, by dividing the counties into three groups on the basis of land values, it is found that in the group of highest price, 29 per cent of the farms are operated by tenants, in the group of medium price, 2I per cent are so operated, and in the group of lowest priced land the percentage is 16 . A similar situation is found in New York, except that the difference betwcen the first and second groups is very much less, due undoubtedly to the ownership of suburban homes mentioned above. In New England the case is complicated by the suburban home-sometimes in reality many miles from the city-and by the various kinds of specialized farming, particularly fruit farming. In New Jersey the greatest percentage of tenancy is on land of medium price, the suburban homes and the fruit farms being plentiful enough to over-balance the tendency of the general farming districts. 
In this section of the country the type of farming shows a clearer line of demarkation between owner and tenant than does value of land. The tenants here, as elsewhere, gravitate toward the farms suited to their immediate wants and powers. The tenant wants an opportunity to make quick returns from small capital. He wants quick returns because he is not financially able to make long-time investments and his short-time investment must be a relatively small one; if he had the means he would buy a farm and cease at once to be a tenant. Hence the tenant wants a farm of such a character that he may be able to go upon it with small equipment and in the space of a single season produce crops which, within the year, may be sold. It is not surprising, therefore, to find the tenants producing much more than their proportional share of the grain. In New York, for example, they grow 50 per cent more than their share of wheat; in Pennsylvania, 75 per cent more, and in New Jersey, 76 per cent more. The same principle holds true in connection with the other leading field crops, corn, oats, hay and forage. Within the counties of all of these states in which the grain crops predominate, the percentage of tenancy is above that for the states as units, and although the land on which such crops are grown is not the highest in price of any in the states, it is well above the average.

As a rule tenants keep much less live stock than do landowning farmers. The reasons for this are clear. They are not able to make the initial investment; they are likely to move every few years and it is not convenient to move live stock and fit the numbers to the barn room and pasture of the newly occupied farm. Moreover, the landlord, while he usually professes to want a tenant who will keep live stock, is seldom anxious to provide the necessary facilities for doing so, and even if one landlord would, the next probably would not, and the tenant does not wish to take the chances. A notable exception to the small amount of live stock kept by tenants is found in connection with the dairy industry, particularly of New York and Pennsylvania. To begin with, dairying is a well-developed business among the farmers of these states, a large number of farms being adapted to it and equipped for it. Hence if a tenant dairyman moves he is likely to be able to find another dairy farm not far away. The question will at once arisehow can the dairy tenant invest in a herd of cows and all that goes 
with it to equip a dairy, while other tenants are unable to keep much live stock? The answer is that he cannot in most cases, but in order to find tenants for dairy farms the landlords have solved the problem by furnishing a large part of the equipment, sometimes all, sometimes half of the cows, and making the tenant a partner in the conduct of the business. This arrangement is not at all usual in the West.

One of the leading types of farming in the East is that of growing fruit. In this connection the tendency in respect to the tenant question is clear cut. The tenant is not a fruit farmer. In the first place the growing of fruit is a continuous process to be begun one year and carried through several, even through decades. The tenant cannot be secure in his possession of a farm long enough to warrant him in planting orchards and vineyards. On the other hand he is rarely such a good fruit grower as to make it desirable on the part of a landlord to trust him with a fruit farm already developed. The State of New Jersey furnishes a good example of the facts of tenancy in its relation to fruit growing. In the counties where the most fruit is produced, the rate of tenancy is in several instances but about half that for the state, and the rate for the state is but about two-thirds as high as for the United States as a whole.

Vegetables, on the other hand, are to a very great extent produced by tenants. As a rule the best available vegetable land is high in price, often high because of other possible uses, and the income from it therefore more or less incidental. It is often rented out for cash to residents of the cities or towns who find it impossible to buy such land, but who are able to plant, tend and sell vegetables, beginning and finishing the process within a year, and so are not seriously inconvenienced by moving if need be from year to year. Some vegetable crops especially seem to fit into a system of tenancy; for example, potatoes, sweet potatoes and tomatoes are grown in various districts to a much greater extent by tenants than by owners.

In the Middle West the tenancy situation is relatively simple, since the types of farming predominating there are fewer and less complex than in the East. For this reason the leading characteristics of the tenant and the tenant farms are more easily traced. There is, however, a very wide range in the character and value of 
farm land within the Middle West. For instance, farms in central Illinois are selling for $\$ 200$ and even $\$ 300$ per acre, while in western North Dakota, or northern Minnesota quotations of fivedollar land are still being made. These are important facts from the standpoint of farm ownership and tenancy. The first and most general fact in explanation of the situation is the coincidence of high value of land and a high proportion of tenant farms. In nine states of the twelve in the North Central division, the rank in tenancy and the rank in value of land, are remarkably similar, the order being from the standpoint of land value, Illinois, Iowa, Indiana, Ohio, Missouri, Minnesota, South Dakota, Michigan, North Dakota; from the standpoint of tenancy, Illinois, Iowa, Indiana, Missouri, Ohio, South Dakota, Minnesota, Michigan, North Dakota. It will be noticed that Wisconsin, Kansas and Nebraska are not included in this ranking. In Wisconsin tenancy has been lower than in other states of this section as far back as the record goes. This is due no doubt mainly to the large numbers of Germans and Norwegians who always buy land where it is possible to do so; to the prevalence of the dairy industry which in the Middle West is carried on very little by tenants; and to the fact that Wisconsin is not as well adapted as most other states of the section to grain farming on the extensive plan. In Kansas and Nebraska the proportion of tenancy is high in proportion to the price of land. Great numbers of speculators from farther east have gone into these states to buy land, and not wishing to farm it themselves have offered it for rent. In no other part of the United States does the tenant find a better chance to do a big business of the extensive farming type than here. He can use as big plows and harrows and seeders as are made. He can sow in the spring and sell in the fall. In Minnesota and the Dakotas, where conditions are somewhat similar, there is still too much unoccupied land to permit of finding tenants. The tenant of other sections is moving there in order to buy for himself, thus making the proportion of owned farms high, and tenant farms low.

On the highest-priced land of Illinois and Iowa, the proportion of tenancy is increasing rapidly, the size of the farm increasing, and the number of rural people per square mile, decreasing. It all seems to be part of a general movement. The land is getting too high in price for a young man to buy. He must be a tenant for 
some years at best, and then the chances are that he will move to a section of country where land is cheaper. But on this highpriced land the tenant can grow grain to fair advantage without great outlay. Meanwhile the owner of the land is looking for only modest returns in the form of rent, since he expects the land itself to increase in value. He believes the fertility of the soil will not be depleted seriously during the time he owns it, and therefore takes no very vital interest keeping it up to its best. This attitude suits the tenant since his interest in the fertility of this particular soil will cease with the termination of his last lease contract and he expects that time to be no great distance off. The whole tenant regime is in this way one of soil exploitation and speculation. The buildings are worth but about five-sixths as much on tenant farms as on owned farms, though the implements owned by the tenant are but little below in value those of the land-owning farmer. The tenant is not noticeably short of equipment in the form of implements. In the matter of cattle and sheep he has but about three-fourths of his proportional share, and he produces a like proportion of the hay and forage crop. It is as a grain farmer that the tenant ranks high. In the production of corn especially the tenant excels, raising one-third more than his relative amount. The same condition holds, though to a less degree, with respect to the production of nearly all other grain crops, though in this division of states low-priced land farmed by the owner is characteristic of the wheat regions and in consequence the higher proportion of wheat is here grown by land owners.

Around the outer portion of this group of states is a belt of country in which tenancy is not so prevalent as in the central portion. In southern and eastern Ohio sheep raising and dairying are the leading types of farming. In Michigan there is much cheap land and much fruit land. In Wisconsin the northern portion is still within reach of the farmer of moderate means. The same is true of Minnesota, while in the Dakotas and Nebraska and Kansas there still remains a little government land to be had at small price or homesteaded. In Missouri, the Ozark district is being sold out in small tracts, largely, for fruit farms. In southern Illinois and Indiana, the character of the country is such that the price of land has remained low. Throughout this entire belt, the rate of tenancy is below half that of the average for the division as a whole. 
In the Western division of states, eleven in number, comprising two-fifths of the entire area of the United States, the number of farms is small, though the character of the agriculture is greatly varied. The proportion of tenancy is for the whole division low, but far from uniformly distributed. The general facts noted in connection with the East and Middle West hold good also in the far West. Here are a larger number of fruit farms in proportion to all farms than anywhere else in the United States. At the same time there are many vegetable farms, while in some sections the genuine grain farms are found in great numbers. The fruit farms are almost altogether in the hands of owners, the vegetable farms very largely in the hands of tenants, while in the grain farming districts although the greater proportion are in the hands of owners, the tenants are in evidence in larger numbers than for the whole division on an average. For example in southeastern Washington a million acres have been added to the wheat fields within a decade, and in this district the tenants are much more numerous than in any other part of the state; they raise much more than their proportional share of the wheat. In the counties of Washington in which fruit growing has had its greatest development tenancy is the lowest of any in the state. The same is true of Oregon, California, and Colorado, the three states in which fruit growing has reached its greatest development in the West.

In all of the Western division of states the proportion of tenancy is low on account of the great numbers of farms recently acquired from the government in the form of homesteads, Carey Act entries and otherwise. These farms are almost necessarily counted as owned farms for several years at least, and since it is difficult to find tenants where land is so easily obtained under ownership, it is likely to be farmed by the owner or not at all. Another class of farms, nearly all of which are operated by owners, are those on which live stock is the main source of income. Thus the live stock and fruit industries, together with the abundance of cheap land suffice to keep the proportion of tenants at proportion but two-fifths as high as that for the United States as a whole.

In the four northern states of the South Atlantic division the proportion of tenancy has decreased during the past decade. These states join the North Atlantic States, and unquestionably the movement over the North Atlantic States together with these four, is a 
common one. In these four states the type of farming is quite like that of the states immediately to the north. For example, there has been recently a great development in fruit growing. Farms have decreased a little in average size. The amount of grain grown has declined. All of these facts point toward ownership rather than tenancy. Farther to the south, and this is the real South, the proportion of tenancy has been on the increase throughout the entire period since 1880 . In these states the situation is essentially different from that of any part of the country. Here, and here only, is there a tenant class-that is to say, the Negroes. Land owners in this section of the country expect to continue some sort of a renting plan permanently. Probably the main reason for this is the difficulty of hiring labor. Since the freeing of the Negroes they have not been a reliable class as farm laborers. After the close of the reconstruction period a system of tenancy developed, ranging from the irresponsible tenant to whom equipment and provisions are furnished in advance of the crop produced, and who, in turn, has little hope of receiving anything more than enough to square him with the landlord, to the cash tenant who pays his rent actually in cash, but of the latter class there are very few. The more usual type is the "standing renter" who delivers a certain prescribed quantity of crop. Socially, he is more independent than the share tenant, economically, he probably is not.

This system of tenancy has often been condemned as malicious, since the tenant seldom makes little more than a bare living and since it is difficult under it to establish a good system of crop rotation, the Negro preferring, wherever possible, to grow cotton and little or nothing else. Nevertheless, it has its good features. Under it the Negro is learning the responsibilities of farm management and is slowly but surely bettering his economic position. Unquestionably the status of the tenant is better than that of the laborer who works here and there by the day, and, for the most part, better than that of the regularly employed laborers. Although the Negroes are acquiring more and more land as the years pass, it is altogether probable that the system of tenancy now prevailing will, with modifications, continue for a long time to come-that is to say, there will be among the Negroes a very large number of tenants. At the present time, in some of the leading cotton-growing counties of Mississippi, the proportion of Negro farmers is 
above 90 per cent and at the same time the proportion of tenant farmers is above 90 per cent-the Negro farmers and the tenants being for the most part the same.

Tenancy is not necessarily bad, though as found in this country it has some very undesirable features. The tenant is a transient, and it is useless to insist that the contract should be made for a long period of years. The landlord himself, who often complains because tenants move so frequently, usually wants to reserve the right to sell his land, and terminate the lease with the sale. The majority of northern landlords are speculators in the sense that they are watching for a chance to sell or buy farms whenever opportunity for profit in doing so presents itself. This being the case tenant problems are subsidiary to the speculative program. It will. be difficult to evolve a good system of tenancy while this condition lasts. In the South farms are much more often viewed as permanent possessions, and there tenancy plans can more readily be put into practice.

The tenant takes little interest in community affairs. The questions of schools, churches, or roads are of small moment to him. He does not wish to invest in enterprises which will of necessity be left wholly, and gratuitously, to his successor. He is little concerned with farmers' organizations. In short, he is in a community but hardly of it. These facts, together with his tendency to exploit the soil are reasons enough why ownership is a better system than tenancy. On the other hand, tenancy often makes ownership possible. A better credit system, and a more economical means of marketing farm produce and buying provisions and supplies would go a long way toward enabling the tenant to buy land at an earlier period of life. Likewise when land ceases to rise so rapidly in value the landlord will learn to watch less anxiously for a chance to sell and take more interest in developing a desirable relationship between himself and the man who tills his land. Until these conditions arrive there will be much to be desired in the American system of tenancy. 